\title{
The Roots of Ejtemaioun Ammioun Emergence and Its Governing Ideas
}

\author{
Mohammad Ali Ahmadi ${ }^{1}$ \\ ${ }^{1}$ Department of Political Science, Faculty of Law and Political Science, University of Tehran, Tehran, Iran \\ Correspondence: Mohammad Ali Ahmadi, Department of Political Science, Faculty of Law and Political Science, \\ University of Tehran, Tehran, Iran.
}

Received: April 28, 2016 Accepted: May 10, 2016 Online Published: June 29, 2016

doi:10.5539/jpl.v9n5p160 URL: http://dx.doi.org/10.5539/jpl.v9n5p160

\begin{abstract}
The first organization party entitled Ejtemaioun Ammioun was established at the first of $20^{\text {th }}$ century. This party at first was established not only in Iran, but also Transcaucasia by the Iranian immigrant. At the end of $19^{\text {th }}$ century, revolutionary movements were initiated in Transcaucasia and Russia, Georgian and Armenia coalitions led it. Due to the reluctance of Muslims and particularly Iranian for cooperating with non-Islamic organizations for the religious purpose, some of the activist Muslim members or close to the Russian Social Democratic Labour Party member tried to establish a community and absorbed them through the establishment of a political party. The organization was founded with the name of Hemat and a significant number of Iranian and native Muslims were organized in this organization. The close relationship of Iranian to Hemat, the Iranian activist immigrants encouraged to establish their own party organization. These persons by following administrative and organizational goals of Hemet party and collaboration with some of its leaders, organized Ejtemaioun Ammioun with the aim of supporting the Iranian migrant workers and expanded its activities toward Iran. Given this background, part of its plan came under the influence of Social Democratic Party's ideas. Ejtemaioun emphasized over the loss of privilege, reform land ownership patron-client relations, and workers' rights by limiting working hours, the right of strike and freedom of trade unions. The prominent feature of Ejtemaioun Ammioun party was mixing religion with their organizational plans. Contrary to the impression prevailing at the time, Ejtemaioun Ammioun tried to show the Social socialist principles do not contradict the Islamic principles andeven many of the principles already existed in Islam. They introduced themselves as the true defenders of Islamic law.
\end{abstract}

Keywords: Ejtemaioun Ammioun, Hemet organization, social democracy, Mujahid, the Transcaucasus

\section{Introduction}

Russia and Transcaucasia in particular, received Iranian emigrants since the mid-nineteenth century. However, the conditions of Iran's evolving society, in the last years of this century increased these emigrations; until the early twentieth century they reached their maximum number. Increasing political activity to make changes at this time, forced the government to put activists under more and more pressure, tyranny and persecution and it left no choice for many of them but to emigrate. Some emigrations also had some economic reasons. Some of these emigrants were some businessmen who were traveling to the southern areas of Russia with the aim of trading and some of them had permanent residence; but many of them were among the farmers, artisans and generally poor economic forces who due to the devastation of Iran's economy, under the influence of excessive foreign investment were experiencing unemployment and emigrated to find work, education and better living conditions (Issawi, 1971: 52). Development of Industries and economic growth in Transcaucasia, following the exploitation of huge underground resources in recent years and becoming one of the industrial centers of Russia (Trotsky, 1971: 36) attracted a large number of Iranian emigrants, in different economic fields. In fact, the tendency to immigrate to this region was the result of coincidence of Iran's economic decline and Transcaucasia's economic growth.

According to the available reports, in 1900 about 100 thousand Iranians resided in Russia. But this number increased in the following years. Blova, Soviet historian who was an Iran expert, believes that the number of Iranians who immigrated to Russia only in 1905 was not less than 300 thousand people (Issawi, 1971: 56). These emigrations mainly occurred in the northern regions of Iran and particularly in Azerbaijan. According to 
Hakimian, only in 1904, about 72 thousand passports were issued from northern areas of Iran to immigrate to Russia and most of them belonged to Tabriz (Hakimian, 1374: 53). According to the consulate of Russia, in Tabriz, they issued 312 thousand visas between 1891- 1904 (Soitikhoski, 1371: 77). This number shows the number of emigrants who crossed the border legally, while many went to Caucasus through illegal routs. We don't know exactly how many people chose illegal paths to emigrate; but a report by Iranian Consulate in Transcaucasia suggests that these emigrants also constituted a considerable number. In Rabi al sani 1318 / August 1900, the General of Iranian Consulate in Tbilisi reported to the State Department that more than 50 thousand people have illegally entered into this area (State Department documents, 24 Rabi al sani 1318). Iranian Consulate in Baku, in Shawwal 1318 / January 1901 reported that at least 20 of the 150 or 200 emigrants have entered this country without visa (State Department documents, 17 Shawwal 1318).

Based on available statistics, emigrants who entered to Transcaucasia were dispersed in different cities of Azerbaijan, Georgia and Armenia. But among them, Azerbaijan received more Iranian emigrants. It was pretty normal, since the major part of emigrants were Azeri. Linguistic and cultural affinities of Iranian Azeri people with citizens of Azerbaijan facilitated their communication with local people and generally made is easier for them to live in this region. There was a more important reason which was the economic aspect. Thriving industries and especially the oil industry in Baku created more chances for workers to find a job in this region (Aliyev, 1360: 18). In the oil fields of Baku, in addition to the workers who had permanent residence, annually a large number worked there as seasonal workers (Arutunian, 1385: 31). Seasonal workers were abundant in other jobs as well. In addition to working in industries, Iranian emigrant workers worked in farming, construction, laboring, portage, railway industries, shop keeping and colportage.

\section{The Political Atmosphere of Transcaucasia}

Different spectra of Iranian emigrants, who travelled to Transcaucasia, faced a different political environment in this area in comparison with the situation in their country. Expansion of industries in Transcaucasia and in particular in Azerbaijan resulted in the growth of the working class in this region. Reduction of oil production in Baku, in the early twentieth century, as a result of extension of economic crisis from Europe to Russia and also its impact on other industries which were associated with oil extraction, including mechanical industries and copper smelting industries, led to massive layoffs (Aliyev, 1360: 32). This crisis also influenced the economy of other parts of the Transcaucasia. From the late nineteenth century, labor movements begun to protest unfavorable working conditions and low wages. Unemployment and hardship resulting from this crisis, expanded labor strikes in the region. Since revolutionary organizations assisted these labor circles, they gradually became more political. At this time in Baku, Russian Social Democratic Labor Party was active among Russian workers. Also, Hunchak and Dashnak parties organized Armenian workers. In addition, independent labor movement was active, as well (Soitikhoski, 1371: 49). In December 1904, labor unrest reached its climax by holding the largest strike (Terminasian, 1371: 18). Until 1905, labor movements started a wave of revolution, not only in Baku, but all over the Transcaucasia. This was a prelude to the Russian Revolution in 1905 in this region.

Unlike the Russians, Georgians and Armenians, Muslims, were less willing to join revolutionary activities in the region. Iranian emigrants were not exceptions (Altstadt, 1992: 39). Indeed, non-Muslims led the revolt and the majority of Muslim community who followed their own values and intellectual principles were not concerned about revolutionary slogans. Before liberals, socialists Muslims in Azerbaijan began to encourage their co-religionists to relinquish their passivity and organized them into a coherent organization. However, the purpose of this group was conducting propaganda activities among Muslims who were not easily attracted to socialist ideas. Thus, with this purpose, an organization called "Hemmat" was formed and began its activity. Hammett was founded in 1904 in Baku. They initially formed an intellectual circle in 1903 and in the following year they began their propaganda activities among Muslims as an organization. Some people including M.G. Maasoumov, Sultan Majid Afendiouv, Asadullah Akhoundov, Mohammad Amin Rasul-Zadeh, Mohammad Hassan Hajinsky and Abbas Kazemi were among the members of this group and the first three men were members of the Russian Social Democratic Labor Party. In the early 1905's Mashhadi Azizbegov and Nariman Narimanof also joined the group and became two of its leaders. These two also were members of the party and were considered among the lower positions (Soitikhoski, 1371: 64).

Hemmat; which was formed as a result of a spontaneous effort by Muslim socialists, after its foundation, became closer to the Baku Committee of the Russian Social Democratic Labor Party and established close relationship and cooperation with them. Since some of the leaders of Hemmat group were among the members of this party, this was quite normal. Despite the fact that Hemmat had close relations with Baku Committee, but this organization retained its independence. This independence rose from the fact that they didn't want to be dissolved in a party in which Russians, Armenians and Georgians were in the lead (Afanasian, 1370: 13). In 
terms of ideology Hemmat was not considered as a full Marxist organization, like Russian Social Democratic Labor Party; because there were different political views and yet tinged with nationalism among them (Afari, 1379: 114); but its backgrounds caused this party to be influenced by the ideas of Ejtemaioun Ammioun. This organization's programs accentuated on freedom of speech, freedom of forming gatherings, freedom of belief and faith, freedom of press, personal freedom and freedom of strikes. In its more radical divisions, it demanded for "eight hours of work for workers' and "confiscation of all state-owned lands and all the lands which belong to the nobles and to large landowners and transferring them to those who work on lands". (Ravasani, 1363: p. 338 \& 339). Soon Hemmat found a considerable position among the Transcaucasia Muslims. Soon a considerable number of Muslim workers were organized in this organization and some of them were Iranians. Yaghikian, from the Social Democratic Party of Hunchak, states that most of Hemmat members were oil workers and a quarter of them had Iranian ID cards (Yaghikian, 1386: 365). Hemmat had an important role in the spread of socialist ideas among Iranians who were living in Transcaucasia. On the other hand, its activities had a great influence on Iranian workers to join regional strikes.

\section{Foundation of Ejtemaioun Ammioun in Transcaucasia}

The aim of emigration of Iranians was to improve their economic and living conditions; but emigrants in Transcaucasia were not experiencing better conditions comparing with their own country and they were also facing numerous difficulties. The majority of Iranian workers lived in extreme poverty and even received fewer wages comparing with native workers (Hakimian, 1374: 51). Poor economic conditions forced them to do any job and to accept very unfavorable working conditions. Those who were working in Baku oil industry, were experiencing a tough condition and most of them were among the workers of lower positions in the industry (Azhir, 2 August 1322: 1). Due to their vulnerable position and extreme poverty, in addition to their employers, local residents also behaved them inhumanly. Local workers and people did not hesitate to slander and defame them and beat them severely (Pishehvari, 1359: 15). Iranian consulate, not only did not support its nationals, but it worsened their situation, as well. Consulate officials under different pretexts seized some or all of their income. They confiscated and plundered the property and life insurance of deceased workers. They also fined and imprisoned those immigrants who had entered the Transcaucasia illegally. This had become a source of revenue for the Iranian consulate (Maragheie, 1364: 48). Such a situation encouraged some Iranian activists in Transcaucasia to establish a political organization with the aim of supporting their compatriot workers. These people, by modeling programs of Russian Social Democratic Labor Party and in cooperation with Hemmatis, formed the first political party which was Ejtemaioun Ammioun of Transcaucasia".

This organization was established in Baku in 1905/1284. Kasrawi enumerates the founders of the Ejtemaioun Ammioun as follows: Narimanof, Souchi Mirza, Mirza Jaafar Zanjani, Mashhadi Mohammad Amouoghli, Mohammad Taghi- Shirin Zadeh Salmasi, Haji Khan, Nurullah Khan Yekani, Mashhadi Mohammad Ali Khan, Mirza Abol Hassan Tehrani, Akbar Oskouei, Hussein Sarabi, Mashhadi Bagher Khan Urmiaie and Mashhadi Ismail Miabi (Kasrawi, 1359: 194). According to Kasrawi, most of founder of this organization were from Azerbaijan. Narimanof was the leader of Ejtemaioun Ammioun. Narimanof who was among the leaders of Hemmat, played a significant role in founding Ejtemaioun Ammioun. Since Iranians inclined to Hemmat more and more, other Hemmatis contributed in this regard as well. Narimanof was among the founders of the Ejtemaioun Ammioun and helped Iranians and this was because of his family background and his intellectual foundations. Yaghikian who was very close to Narimanof, believed that his love for Iran and his sentiments is one of his intellectual characteristics. According to Yaghikian, since Narimanof was originally an Iranian and his ancestors were from Urmia, who immigrated to Caucasus later, he felt a special closeness towards Iran and Iranians throughout his life and even his sectarian views and his orientation toward Bolsheviks was formed under the influence of this patriotism; because during the contract of 1907 between Russia and Britain, unlike the Mensheviks, he supported Iran (Yaghikian, 1386: 367). With such sensitivity he could not be indifferent towards the problems of Iranians living in Caucasus and it was quite normal for him to help them to be organized in order to acquire better living conditions and to found an organization with the aim of supporting Iranian emigrants.

Now that Ejtemaioun Ammioun had emerged as an organization, it needed sectarian planning and organizing. Position of Narimanof in the organization and his great experience in sectarian work, raises this possibility that he has prepared the initial plan and the management plan for this organization. Narimanof learned Persian language in a mosque in Tbilisi with the help of a mullah who was from the city of Salmas and he was quite familiar with it (ibid: 368). On the other hand, he was working in Hemmat and the Russian Social Democratic Party, at the same time, while other founders hadn't such a background. Accordingly, Blova believes that program of Ejtemaioun Ammioun is a copy of that's of Hemmattis (Shakeri, 1384: 210); but the sectarian program that is currently available has been developed and approved in 1909/1288; while Ejtemaioun Ammioun 
had their own doctrine and charter at this time. That's why Shakeri rejects Blova's belief. However, this possibility also cannot be ignored that the program may not have been the initial program of Hemmattis and as Sohrab Yazdani states, it is possible that Hemmatis have followed a program and constitution, which has not been found yet (Yazdani, 1391: 168). If we consider this assumption to be true, then we can say that Ejtemaioun Ammioun copied organization and programs of hemmattis.

Anyway, the influence of program of revolutionary parties of Caucasus and in particular the program of Russian Social Democracy Party -through hemmattis- on Ejtemaioun Ammioun seems to be indisputable. Narimanof who was a member of this party and was familiar with its programs, was the most important factor for this influence. So, we can say that Narimanof particularly by utilizing this party's program or the program of other regional revolutionary parties and in accordance with the conditions of the party, mental awareness its members and its translation into Persian developed and formulated an initial program for Ejtemaioun Ammioun. It seems this is the same program which was discovered by Saleh Aliev, -the Soviet Iran expert- and it is known as "program of Baku". The program of Ejtemaioun Ammioun which was approved in 1907/1286 in Mashhad was also drafted according to this document. Another person was Haydar Khan Amouoghli who was the founder of Tehran branch of Ejtemaioun Ammioun and was considered as an influential activist in Iran. He had previously some connections with revolutionary circles in Caucasus and at the time of his activities in Iran, he was associated with the Russian Social Democratic Labor Party.

\section{Developing Activities to Iran}

Soon branches of Ejtemaioun Ammioun were established in Caucasus and Iran. Its branches initiated their activities in Tbilisi, Yerevan, Petrovsk and Kars. There were also branches in Iran. These branches were established in Tabriz, Urmia, Tehran, Mashhad, Rasht, Anzali, Astara and etc. Tabriz was one of the main centers for activities of Ejtemaioun Ammioun. When Kasrawi discusses their activities in this city, he refers to two groups. The first group was those who had returned from Caucasus and since they wore Caucasian costumes, they were called "Caucasian Mojahedin" and the other group was those who had risen from Tabriz themselves (Kasrawi, 1359: 391). According to him, some of the founders of the Ejtemaioun Ammioun in Caucasus returned to Iran to continue their political activities, to help to constitutionalists and to organize their activities inside Iran. In addition, when Taghizadeh sends a letter to Edward Brown to describe biographies and condition of the martyrs of Tabriz uprising in September 29, 1912, he refers to the "Caucasian Mojahedin" as a separate group (Brown, 1351: 203). This group has also been mentioned in a letter that Mohammad Taqi Sadeghof, a member of this organization has sent from Baku to members of Ejtemaioun Ammioun in Tehran (Raein, 1358: 58). This group also expanded their activities to Urmia (Rasoulzadeh, 1387: 177). The second group was those Tabrizis who worked under the leadership of Karbalayi Ali, who was known as "Mosio". According to Kasrawi, this group also was formed in Caucasus to follow Ejtemaioun Ammioun Party and they regarded their "charter" as a guide for their activities (Kasrawī, 1359: 194). Ali Mosio was a merchant in Tabriz who frequently travelled to Istanbul to do his business and during his trips; he usually stayed in Tbilisi and contacted regional activists. During these contacts, he met Narimanof (Javid, 1358: 18). During this meeting, Ali Mosio was introduced to Ejtemaioun Ammioun Party in Caucasus, which was led by Narimanof. Coincide with the constitutional movement; he decided to found such organization in Tabriz. The Central Committee of this organization was called "occult center" (Ebrahimof, 1360: 67).

The Ejtemaioun Ammioun was active in Tehran, as well. Tehran branch of the organization was founded by Haydar Khan Amouoghli. Haydar Khan was originally Iranian and he was trained in the political atmosphere of Caucasus. Throughout his life in Caucasus, he became acquainted with socialism and he had some relations with some revolutionary activists and Ejtemaioun Ammioun in Caucasus (Dastmalchi and shakeri, Bita, 9). He then returned to Iran and played an important role in the expansion of activities of Ejtemaioun Ammioun in the country. Some information about establishment of Tehran branch of Ejtemaioun Ammioun can be obtained by reading Haydar Khan's diary which has been written by Mr. Monshizadeh and has been published in the journal of Yadegar. As he says in his diary, when Mozaffar Din Shah and Atabak went to Baku, they tried to employ a Muslim engineer to set up Mashhad power plant. He was introduced by Muslims in Baku and came to Mashhad to do this job. During his residence in this city, he attempted to set up a party similar to Russian parties, but no one accompanied him except Mashadi Ebrahim Milani. Haydar Khan who saw that Mashhad is not suitable in this regard decided to go to Tehran (Yadegar, January 1325: 63). In Tehran, he organized the central committee of this organization, in collaboration with some revolutionaries, including Malek Almotekallemin and Seyyed Jamal Vaez, (Yadegar, December 1325: 50). Haydar Khan informed the Russian Social Democratic Party, about formation of this committee in Tehran. This party asked him to join their organization to Hemmat and to Ejtemaioun Ammioun and to set up their branch in Tehran (Yadegar, January 1325: 70). 
Branches of Ejtemaioun Ammioun were also formed in Gilan. These branches were organized and established in Rasht and Anzali under the supervision of representatives of Caucasus Center and in cooperation with local activists. According to reports of Rabino, the British consul in Rasht, the members of Ejtemaioun Ammioun in this city coordinated their activities with Caucasus Center. They could accept members in the private areas, after approval by associated members and members of Caucasus Center (Roshan, 1352: 102). Another branch of Ejtemaioun Ammioun in Gilan, was Anzali Branch. This branch was also founded by delegates from Caucasus Center (Yazdani, 1391: 157). Also, Mohammad Amin Rasulzade has referred to a branch in Astara in his reports on Constitutional Revolution (Rasoulzadeh, 1387: 97). As the statute of Ejtemaioun Ammioun adopted in Mashhad explicitly mentions; other branches were also established in Mashhad and Isfahan (Shakeri, 1358: 22).

\section{Political Activity}

In Tabriz, Ejtemaioun Ammioun was involved in the political developments related to the second wave of Constitutional Revolution. At this time, Tabriz association which led the uprising in this city against the Minor tyranny was one of the main arenas for their activities. Ejtemaioun Ammioun had a considerable influence on the decisions of Tabriz association and in many cases they led it indirectly (Rafeie, 1362: 29). One of the impacts of Ejtemaioun Ammioun on this association was this issue that they caused their political stances to become more radical. Spring Rice, a British diplomat in Iran, in a confidential report to Edward Grey, the Secretary of Foreign Affairs, writes:

"An independent parliament has been established in each city and they are conducting their activities without consultation with the governor or the central parliament of Tehran; but the activists are unknown. The source of inspiration is apparently north of Iran, or it may be Caucasus.... this spirit is stronger in Azerbaijan"(Bashiri, 1363: 91).

In addition, Fedayeen (self-sacrificing) groups of Socialists were active in Azerbaijan armed uprising. Caucasian Democrats not only were themselves present at the scene of confrontation with government forces, but they contacted with the Caucasus center and summoned more Fedayeen forces to Tabriz. As Sedeghof has also written in his letter, at this time different branches of Ejtemaioun Ammioun in Caucasus were trying to send troops and ammunitions in order to help uprising in Tabriz and in other Iranian cities. The head of the Committee of Ejtemaioun Ammioun in Tbilisi had promised Sattar Khan to strengthen his forces in their fight against Rahim Khan. In this regard, the Tbilisi center began to negotiate even with Armenian and Georgian in Caucasus (Raeini, 1358: 56). Members of Ejtemaioun Ammioun in Caucasus, not only participated in Tabriz uprising, but they became involved in other cities as well. At this time Rasoulzadeh who immigrated to Iran, following the repression of Hemmat organization and during Stolypin time (Afanasian, 1371: 13) and was preparing reports based on its developments in order to write in "Taraghi" newspaper, in one of his articles, regarding the situation of revolution in Urmia, refers to the participation of Caucasian Fedayeen Socialists, under the leadership of Mashhadi Baqir and Mashhadi Ishmael, in the uprising of this city (Rasoulzadeh, 138: 177). Also, Members of Ejtemaioun Ammioun in Tabriz who were very influential organized a considerable number of young people in Fedayeen groups, in order to launch an uprising against Mohammad Ali Shah. In addition to their armed conflicts, these groups were also responsible for protecting the neighborhoods and streets (Taherzadeh Behzad, 1363: 71). Members of Ejtemaioun Ammioun in Tabriz had some connections with revolutionaries in other cities and assisted them by sending troops to them.

Also in Gilan, Members of Ejtemaioun Ammioun joined the Constitutional Movement. Prominent members of Ejtemaioun Ammioun in Rasht formed the main body and the most influential members of "Sattar Committee". This committee was established by liberal leaders of Rasht to consolidate the uprising. In addition, Ali Mohammad Khan Tarbiat, a member of Ejtemaioun Ammioun in Tabriz, who came to Rasht at this time, was also a member of this Committee (Malekzade, 1363: 1051). Their membership in both Sattar Committee and Ejtemaioun Ammioun created close relationships among these two groups. Letters of Qazvin branch of Sattar Committee indicate this close relationship very well (Afshar, 1359: 496). Members of Ejtemaioun Ammioun in Rasht were engaged in holding political meetings, in addition to participating in Gilan uprising. "Modern Iran" newspaper, in one of its issues stated that members of Ejtemaioun Ammioun in Rasht have held a tribute for "Ferrer" the Spanish Socialist, in October 1909 / November1288. The news had declared that:

"In the eleventh of Shawwal, after the execution of Monsieur Ferrer, by Spanish government, this afternoon, a delegation from Ejtemaioun Ammioun, along with a large number of people will be gathered in the streets, in Rasht, with playing music and elevating banners and they sang Marseillaise anthem, in the memory of the leader of the socialists, "(Modern Iran, 13 of Shawwal 1327: 3).

Also members of Ejtemaioun Ammioun in Anzali joined to the "secret committee" to organize uprisings in this 
city (Fakhraie, 1352: 114). In addition, they launched fishermen's uprising against patents of Russian Liazanov (Adamiyyat, 1388: 21 and 73).

The most important organizational objective for Tehran branch of Ejtemaioun Ammioun was preserving Constitutional Revolution. In this regard, the leaders of this branch even resorted to assassination. Mohammad Ali Shah summoned Atabak -who was inclined to Russia- from Europe to Iran to entrust him the chancellorship position. The Ejtemaioun Ammioun Center in Caucasus considered this issue as a threat to the Constitutional Revolution, because they believed that through him the king will try to suppress the revolution. When Atabak intended to enter Iran through Caucasus, Fedayeen Socialists of Baku attempted to assassinate him; but they didn't succeed and they shot someone else by mistake (on 1352: 14). When Atabak returned to Iran, Tehran branch of the Ejtemaioun Ammioun decided to put the implementation of this assassination on its agenda. The occult center of this branch announced its final warning to him, through Sadegh Tahbaz, a member of the organization, during a personal meeting (Rezazade Malek, Bi Ta: 71). Finally the occult center decided to kill Atabak and it assigned this mission to Abbas Sarraf Tabrizi (Yadegar, October 25 1325: 50). Before performing the mission, he sent some letters to Atabak and asked him to give up his opposition against Constitutional Revolution and the parliament; but since it didn't work, he implemented the decision.

After conquering Tehran and on the verge of establishment of the second parliament, some of the influential and activists Ejtemaioun Ammioun turned to parliamentary activities and assembled in Democratic Party of Iran. Some others also joined other parties. Therefore, activities of local branches faced severe downturn. Eventually the Caucasus Center decided to close its branches in Iran and it declared in a statement that the activities of Ejtemaioun Ammioun in Iran is suspended until establishment of appropriate conditions in the future (Modern Iran, 20 Muharram 1328: 4); conditions which were never provided for continuation of activities of this party in Iran. Also after defeat of Mohammad Ali Shah, activities of Caucasus branches depended on supporting Iranian citizens working in this region. As we mentioned, not only the internal organizations of Ejtemaioun Ammioun were active in Constitutional Movement; but Caucasus branch were also involved in domestic developments. One of other activities of Ejtemaioun Ammioun of Caucasus, both during the revolution and after conquering Tehran, was trying to improve condition of Iranian immigrants and especially laborers in this area. In fact, this was one of the most important objectives of establishment of Ejtemaioun Ammioun. These branches, especially in Baku and Tbilisi were trying to control and reform difficult working conditions for Iranian emigrant workers, by issuing statements and announcements. The Center of Ejtemaioun Ammioun in Caucasus was frequently in contact with the Parliament and the Ministry of Foreign Affairs and it reported situation of Iranians living in Transcaucasia to these bodies and demanded them to try to improve their condition.

\section{Sectarian Press}

These Ejtemaioun Ammioun published the "Mojahed" newspaper in Tabriz and Rasht. The first issue Mojahed was published in Tabriz on 18 September 1907/26 Shahrivar 1286 and it was published in Rasht, about two months later, on 16 November 1907/24 Aban 1286 (Mojahed (Tabriz and Rasht), 9 Shaaban, 9 Shawwal 1325, frontispiece). Mohammad shabestari known as Abolzia, published the Mojahed newspaper in Tabriz (Brown, 1914: 131). In the frontispiece of Mojahed newspaper of Rasht, it was written that: "manager and owner, holy sect of Mojahedin, Darolmarz-Rasht". Mojahed published 22 issues in Tabriz and its latest issue was published on 14 December 22/1907 Azar 1286 and it published 5 issues in Rasht and the latest issue was published on 5 February 1908/15 Bahman 1286 (Ibid, 131: 132). Both of these newspapers expressed ideas of Ejtemaioun Ammioun of the two cities and they declared orientation of their organizations regarding current developments. However, Mojahed of Tabriz usually didn't directly mention the party, while Mojahed of Rasht openly expressed ideas of "holy sect of Mojahedin, Rasht Center". Among the issues of Mojahed of Tabriz, only in the ninth issue we see the phrase "sect of Mojahedin" (Mojahed (Tabriz), 15 of Ramadan 1325: 3). Mojahed of Rasht engraved the famous slogan of Ejtemaioun Ammioun which was "freedom", "equality" and "justice" on its frontispiece and some articles were published by signature of "sect of Mojahedin". These newspapers wrote about the necessity of supporting the Constitutional Revolution and parliament and paying more attention to science for development and establishment of new schools. These two newspapers did not offend the king; but they had radical stances against the others. Mojahed of Tabriz revealed its enmity toward Atabak, since publishing its first issue. In its third issue, this newspaper dedicated the whole of its first page to publish a photo of Abbas Agha Sarraf Tabrizi, the assassin of Atabak who was a member of Tehran branch of Ejtemaioun Ammioun and while writing an article in his support, it called him "slain for homeland" (Mojahed (Tabriz), 22 Shaaban 1325: 1 and 2).

It should be noted that a number of revolutionaries who had joined the Ejtemaioun Ammioun, including, Seyyed Ashraf aldin-Gilani, Seyyed Mohammed Reza Shirazi, Mirza Jahangir Khan and Ali Akbar Dehkhoda, alongside 
their activities in the organization, they were also journalists. Ashraf al-Din and Seyyed Mohammed Reza Shirazi, respectively published the newspapers of "Nasim Shomal" and "Mosavat" and Mirza Jahangir Khan Shirazi and Dehkhoda published "Souresrafil". Some of them attempted to promote the Ejtemaioun Ammioun and their opinions in their own press and newspapers. Seyyed Ashraf aldin-Gilani who published Nasim Shomal in Rasht, occasionally revealed his interest and attachment to this organization in his articles. For example, when he states that Iranians are the most oppressed nations at home and abroad, in one of the issues of Nasim Shomal and calls for unity between "lawyers", "ministers", "priests" and "women" and "men" for elimination of injustice and "in the path of Constitutional Revolution" and "realization of national rights" he ask Ejtemaioun Ammioun to assist to save the country. He called, Ejtemaioun Ammioun with phrases like: "the sacred sect of revolutionaries" and "O, youth who have planted the tree of liberty and constitutionalism in Iran" and he asks them to protect the Constitutional Revolution against the "tyranny" and to save the country's independence against Russia and Ottoman (Nasim Shomal, 7 Muharram 1326: 1 and 2). His Supportive view for Ejtemaioun Ammioun is more specifically evident in another issue of Nasim Shomal. Apparently the newspaper of "Hablol Matin" had called the Ejtemaioun Ammioun of Caucasus in an article to be "anarchists" and had attacked this organization. In response to Hablol Matin, Nasim Shomal writes:

"... Hablol Matin, the entire world knows how much the veteran refugees of Mojahedin in Caucasus have struggled at the beginning of constitutionalism. Many were murdered. Even to some extent they became a tool to promote constitutionalism in Caucasus. They even encouraged and reassured journalists and some lawyers. They lost their lives and firmly grasped the Constitutional Revolution. Is it right to call those liberal and brave men anarchists in Hablol Matin "(Nasim Shomal, 26 Safar 1326: 2 and 3).

In addition, Seyyed Ashraf al-Din, by writing the awakening letter of Ejtemaioun Ammioun of Rasht (Nasim Shomal, 23 Rabi al-Awwal 1326: 3) and other materials associated with the organization, in other issues of Nasim Shomal revealed his intellectual and political affinity with this party. Also, Souresrafil in several issues and in the form of a series of contiguous articles, tried to promote programs of Ejtemaioun Ammioun, without mentioning the name of the party (Souresrafil, 21 Shawwal 1325 to 24 Rabi Thani 1326).

\section{Organizational Structures}

Sectarian organization of Ejtemaioun Ammioun is based on secrecy, secret activities and strict organizational hierarchy. Different branches of Ejtemaioun Ammioun, since its foundation in Iran that was about October 1906 / Mehr 1285 to September 1907 / Shahrivar 1286 that its General Assembly was held in Mashhad had not a unique organizational statute; but their sectarian system which was modeled according to the Caucasus Center, was more or less in common. Two active groups in Tabriz enjoyed a relatively similar organization, because as we saw previously, both of their organizational plans stem from one root. Like the Caucasus center, they had Central Committee and the private domains with limited members in the upper ranks of the organization. The head or the Chairman of the Central Committee led the organization. The committee was considered as the main decision-making body. Also, general domains were active under the supervision of the Central Committee. Some of the members of private domains were active in the general domain $\mathrm{s}$ as well (Fathi, 1352: 8). In addition, there were some groups called "Fedayeen" within Ejtemaioun Ammioun which formed armed groups of this organization and were responsible for conducting military operations. These groups often worked under the auspices of general domain. Fadaiyan usually performed their armed actions collectively; but they sometimes carried out solo missions, as well (Sardari Nia, 1363: 48). They selected individuals to carry out the mission by using drawing or lottery. General domain and Fadaiyan were obliged to carry out Central Committee's orders. Secrecy was one of the basic principles of this organization. Keeping corporate secrets by members was strongly emphasized and negligence in this regard could result in harsh punishment for offenders. All the members were obliged to refuse to reveal their organizational affiliations, in the case of arrest, under torture and even in the face of death. Secrecy was also observed within the organization itself. The composition (identity of members) of the Central Committee was unknown to the members of lower ranks. Members of general domain were in contact with the Central Committee and received necessary commands only through their head (Azari, 1352: 79). As it is evident, the leaders of the occult center have observed all the precautions in recruitment of new members. Organization members encouraged certain people who knew them themselves closely and were familiar with their characteristics to join the party. These people wrote a request and referred to the occult center along with their recommender. Then this center would issue a membership card for them, after extensive research about the volunteers and confirming their conditions. Then these people will be called to the occult center to explain organization rules and regulations to them. These meetings were held in complete darkness, so that the identity of the members of the center remains totally unknown for the new member (Taherzadeh Behzad 1363: 63).

Also, in Tehran branch, Secrecy both inside and outside the organization was the main feature of the Ejtemaioun 
Ammioun in this city. Haydar Khan in his diary refers to the existence of two secret and general domains, executive committee and board of Madhasheh in this organization (Yedegar, December 1325: 51). The secret domain was the main decision-maker. Executive committee worked under its supervision. Also executive committee led the Fadaiyan group. At the top of Fadaiyan group the Board of Madhasheh worked and it implemented the commands. Like Tabriz and Tehran, the Rasht branch also had two private and general domains. Rabino in his reports about the Constitutional Revolution in Gilan writes:

"Fedayeen have two meetings. One is general meeting which is held in public and anyone can attend it and the other one is the secret meeting which has strict rules ... members who attend the meeting swear not to reveal the place and if one of them reveals the information, they must kill him"(Roshan, 1352: 102).

Over time, party leaders decided to create similar organizational rules for all branches and they approved statute by holding the General Assembly in Mashhad. This statute stipulated that the main center of Mojahedin will be Caucasus as before. According to the statute, the Central Committee of Party must not have less than 15 members. Some of the duties and the rights of the Central Committee included: ordinary and extraordinary meetings, assigning affairs to different branches, sending experienced speaker or printed materials and explosives to different branches, monopoly on the basis of membership papers, dissolution of branches in the case of inactivity and establishing another branch and authorizing them to set up branches in different locations. Also, regarding the rights and duties of the branches the important issue was secret party activities. On this basis, the branch should not give anyone the address to the Central Committee and telegraph communication with the Central Committee must be performed by using special codes which must be known only for the head of the branch. According to the statute, the permanent members of the private domain must be at least 7 and maximally 11 people. This domain shall be so secret that no one, even the members could connect it except through the general domain; members of general domain should not try to discover the location of private meeting and if someone does so, he will be punished; the private domain leads all members of the branch and it must report its activities to the Central Committee (Shakeri, 1358: 19-16).

Organizational rules in this statue predicted strict penalties for those offenders who ignore regulations. Accordingly, two general and private courts were predicted to conduct the trials. The private court was responsible for the trial of members of the private domain or the heads of Fedayeen and the general court was responsible for trial of members of general domain. Four different punishments were considered for offenders: dismissal, fines, detention and execution. Those who committed a treachery by mistakes or because of their ignorance were reprimanded. The execution was applied to these people: Someone who betrays members of private or public domain and delivers them to the government officials; anyone who forges their seal or writes a letter under the title of Fedayeen; any member who reveals a secret and betrays them knowingly and intentionally; anyone who shows indifference toward funds and weapons; anyone who commits a cardinal sin against the religion, people and the country and anyone who does some measures against the country, knowingly and deliberately who is caught two times. Those who commit some less important sins will be arrested, fined or dismissed, according to the court (ibid: 24-22).

\section{Ideology of Ejtemaioun Ammioun and Their Attempts to Institutionalize It}

Some of the organizational purposes of Ejtemaioun Ammioun included: emphasizing on protection and improvement of lower classes affairs and maintaining their rights against the upper classes, establishment of equality, justice and freedom. Programs of this organization supported the rights of farmers and workers working in different economic sectors and poor people, such as lone women, orphans and elders. Sectarian views of Ejtemaioun Ammioun are reflected in two phases and within two documents. The first document that is known as "Baku program" represents organizational program of this party in its early phases. This document is a program that Saleh Aliyev, the Soviet Iran expert published in 1965 in an article in the magazine of "peoples of Asia and Africa". According to him, the magistrate of district 3 of Baku on December 4, 1906 reports to the prosecutor that the manager of one of the print shops has informed him that several armed men have entered his print shop and after arresting the staff they have published three thousand copies of a pamphlet which was typeset and presented before. After their departure, several pages of a pamphlet which was printed in Farsi were found and archived in the court of Baku. As Aliyev believes this document which contains organizational purposes and a sectarian program belongs to the Ejtemaioun Ammioun, because in 1906 only one Iranian party was active in Baku (Shakeri, Bi Ta, 38).

Some part of this program which is available now begins with an introduction and then points out some issues and then explains different types of freedom. Different sections of this program emphasize on the rights of the most vulnerable social classes. The first article specifies the Agrarian Policy of the Party and it is about the rights 
of the farmers. This article considers confiscation of farmlands and dividing them among farmers. The second article refers to the number of working hours per day and it says that workers should not be forced to work more than eight hours, unless they decide to do so to acquire more money. In Article Three it regards the rights of women, orphans and elders, where it states that the government must protect and support widows, orphans and those elders who are unable to work because of their senility. Also the government must consider subsidy for them. Article four regards poor people and the duty of the government toward them. Also Article five emphasizes on the construction of schools for orphans and poor people in different cities and villages. Articles six and seven consider programs on taxation and customs. These Articles as the previous article support poor people and destitute. In another section of this document, the liberal party is being introduced and it expresses its purpose as rescuing people from regime, officials and authorities. Then it talks about realization of six types of freedom as its purposes: freedom of consultation, freedom of speech, freedom of press, freedom and unity between owners of industries and intellectuals, freedom of religion and freedom of shutdown (strike) (Shakeri and Dastmalchi, Bi Ta: 145).

Another document which has remained after Ejtemaioun Ammioun is the manifesto of this organization which has been approved during the party's General Assembly in Mashhad and coincides with approval of its statute. Dispersion of different branches of Ejtemaioun Ammioun in Iran and the necessity for compilation of a unique program for them and adaptation of new program with spatial and temporal conditions were among the reasons to hold this assembly. It seems that different branches of Ejtemaioun Ammioun in Iran did not have a unique program. According to Aliyev, domestic branches didn't have a common manifesto for all of them to follow. However, some branches like Tabriz which was inspired by the program of central party in Caucasus developed a program for themselves (Shakeri, Bi Ta: 39). Mashhad manifesto reflected the contents of Baku program more or less, but it considered some considerations in expressing its sectarian purposes. Baku program was not in full compliance with the conditions prevailing in Iran's society. On the other hand, important developments had occurred in the country which required to be considered. Establishment of constitutionalism and formation of National Consultative Assembly provided a reliable power which could facilitate achieving organizational purposes. Mashhad manifesto tried to take into account spatial and temporal needs. According to manifesto, national parliaments and constitutionalism, expanding Justice and equality are the only means of defending the nation, homeland and elimination of tyrant. Socialists emphasized on the existence of a party in Iran to take all the required measures to protect and support the nation and the National Assembly and therefore they believed in the necessity of existence of the Ejtemaioun Ammioun in Iran as a part of the constitutionalism. Thus, according to the time conditions, the manifesto prioritized supporting the National Assembly and constitutionalism in order to achieve organizational purposes. Thus, some Articles were allocated to elections and the parliament (Union, 1371: 345).

Another important point was that the manifesto considered the religious aspect of Iran's society, as well. Baku program emphasized on religious freedom and certainly this issue could become an excuse for oppositions and this could create conflicts in the society. On this basis, the issue of freedom of religion has not been mentioned in this manifesto. On the other hand, many members who had religious origins believed in the integration of religion with sectarian programs. Accordingly, the manifesto called the organization "Mojahedin" and emphasized on religious aspects of "Mojahed", and by stating the verse "human will only achieve what he has tried for" it declares:

"This verse indicates the high and holy stance of efforts of Mojahedin and their dignity. It is necessary for anyone who wants to enter to this group to understand the real importance of jihad and the objectives of this group and only then he can call himself with the glorious title of Mojahed"(Ibid: 346$)$.

Agrarian Policy of the Party was also one of the considerations of those who developed the manifesto. The land policy in Baku program has discussed about confiscation of most of farmland and to give them to the farmers. While the Mashhad manifesto is more careful and conservative regarding private properties of big owners. Mashhad manifesto has suggested purchasing farmlands from big landowners and this issue indicates their conservative and cautious approach in this regard. Based on the knowledge of Ejtemaioun about Iran's system of land ownership, they concluded that confiscation of lands which belong to big landowners will create huge oppositions by various social classes. It should be noted that due to the integration of Iran's economy in the global economy, land became as an important source for production of monetary goods for export and obtaining great profits. This issue urged some officials, clergymen, businessmen and regional and local heads and authorities toward possessing more lands (wallerstein, 1974: 401). These social forces enjoyed considerable influence in the power structure or in society and some of them were considered among the Constitutionalists. Naturally, Ejtemaioun who intended to consolidate their position in Iran and considered themselves as a 
component of constitutionalism, didn't want to confront them, so they found it necessary to raise this issue -Agrarian Policy- more moderately.

The manifesto, then discussed the need for settlement of poor people by government, exemption from taxes and customs for those who do not have property and business income, taxation based on the assets and capital, forming a systematic army and mandating conscription for all people in every class and restricting working hours to less than eight hours per day (Union, 1371: 347).

In general, based on what we mentioned before, some parts of the programs of Ejtemaioun Ammioun were stemmed from social-democratic ideas. They emphasized on the elimination of class privileges (Hablol Matin, 2 Rajab 1325: 13) dividing the lands, respecting workers' rights by limiting working hours, the right to hold strikes and freedom and the right to form trade unions. In practice, they took some steps toward their desired objectives and in particular they tried to implement Agrarian Policy. Caucasian Socialists, after coming to the city of Tabriz and establishing connections with the State Council in this city, on the basis of Azerbaijan's Agrarian policy, offered this Council to divide farmlands among peasants (shakeri, 1384: 189). Since some of the members of this Council were among the regional landowners, it was normal for them to oppose the implementation of such a plan. As we discussed it before, this experience urged Ejtemaioun to reconsider their Agrarian Policy in compilation of Mashhad manifesto. Two months after drafting and adoption of this manifesto, the weekly of Souresrafil, by printing a series of contiguous articles tried to institutionalize this Agrarian policy, while it didn't mention the name of the organization. Some of these articles were published with the signature of "A. A. D "(Ali Akbar Dehkhoda), but it seems that all of them were written by Dehkhoda. Souresrafil in its 18th issue on the issue of reforming agricultural system, writes:

"If we ask any expert in Nations Economic about Iran's economic resources; inevitably first of all he will mention the development of agriculture and undoubtedly as it is evident for everyone, the most important resources of a country are land and labor and agriculture is the first results of these two great sources of wealth" (Souresrafil, 21 Shawwal 1325: 1).

The author recalls the catastrophic situation of peasants in Iran and exploitation of a large portion of their income by landlords and refers to the fact that "courage, energy and persistence are the best potions for the production of wealth in the world and they will be abundant in a worker only when he observes that he benefits from the whole or at least the major part of his labor himself" and he indicates that "the first means for production and increasing wealth is extension of agricultural benefits and undoubtedly this issue depends on absolute certainty of peasant about benefiting from his labor". He believes that "weak extension of agriculture in Iran" and "nationwide poverty" and immorality of peasants (for instance stealing crops) are the results of feudalism system and he stipulates that:

"To prevent this nationwide poverty and contagious moral corruption, undoubtedly the best resort and the last exclusive remedy is to grant the peasants those lands which they work on" (ibid: 2).

In the next issue, Souresrafil discusses considerations which have been considered in the new agrarian policy (Souresrafil, 28 Shawwal 1325: 2). Author in issue 21 of Souresrafil believes that implementation of his proposed plan will be practical only through the establishment of "national agricultural bank" and specifically explains the role of this bank in purchasing lands from their owners and to sell them to the peasants (Souresrafil, $18 \mathrm{Dhu}$ al-Hijjah 1325: 2). Then in the issues 24 to 27, he writes about the efforts of representatives of Russian State Duma, to pass a law to transfer "state lands" properties "churches" and "landlords' properties" to the farmers and their confrontation with governmental sabotages in this regard. Then, the author in the issues 29 and 30 responds to the objections and criticisms raised to the land ownership reformation plan and dividing lands among farmers and defends it by presenting some evidences and documents (Souresrafil, 12 and 24 Rabi Thani 1326: 1 and 2). It should be noted that Souresrafil didn't only try to promote the Agrarian Policy of Ejtemaioun, but it attempted to develop some of other programs and plans of this sectarian party. This journal also argued the necessity of forming disciplined armies in Iran and mandating conscription for all people (Souresrafil, 11 Dhu al-Hijjah 1325: 3) and reforming Iran's taxation system to the benefit of the peasants (Souresrafil, 1 Dhu al-Hijjah 1325: 2).

Integrating religion with sectarian programs and respecting and believing in it, was one of the most significant aspects of Ejtemaioun Ammioun. Its formulary requires members to pay their membership fee according to principles of holy Quran (Article 6). It also stipulates that members must attempt to move toward progress and development, but this should not impair and harm the holy religion (Article 11) (Shakeri, of Bi Ta, 42 and 43). Also, Mashhad statute and manifesto were adopted on the birthday of Imam Mahdi and this issue has been emphasized in the text of the statute. In addition, the statute insisted on writing the phrase "In the name of Allah 
who grants us freedom" on the top of those letters which branches send to the Central Committee or to each other (Article 33). This statute considered death penalty for those members who commit a cardinal sin, based on the holy religion (Article 46, paragraph 5) (Shakeri, 1358: 18). As we mentioned earlier, the manifesto of the Ejtemaioun Ammioun also considered members of the party as "Mojahed" in its religious sense. Belief in the religious principles and Islam had a special status among Ejtemaioun of Tabriz. This issue was so important for the leaders of the occult center that they considered "belief in the religion of Islam" as a basic requirement for membership in this organization (Fathi, 1352: 8).

As we saw in the available documents, Ejtemaioun also used the terms "Mojahed" or "Mojahedin" to call their organizations. This term sometimes was used along with "Ejtemaioun Ammioun", for example "Mojahed Ejtemaioun Ammioun" or "Mojahed sect, Ejtemaioun Ammioun of Iran" and sometimes "Mojahed sect" or "Iranian Mojahedin center" were applied to name this organization. Adamiyyat says the term "Ejtemaioun Ammioun" was an unknown term for people, so they may have used the term "Mojahed" because it was easier to be used (Adamiyyat, 1388: 17); but it seems that they have attempted to introduce themselves as fighters in a holy path, in this way. In their view, Mojahedin were those who were scrambling to achieve a sacred goal, for example to found the constitutionalism and to establish its elements. They believed that fighting for constitutionalism is jihad for the sake of God, so they emphasized on the religious aspect of Mojahed. Mojahed newspaper in one of its articles, describes the interpretation of Ejtemaioun in this context which originates from Shiaism. This newspaper writes:

"The word "Mojahed" is a divine word and it has been mentioned in holy Quran. As in a verse we see that holy Quran states "God preferred Mojahedin over Qa'edin" and all of Shiite scholars believe that this verse is a strong and valid reason for preferring Imam Ali over three caliphs; because Imam Ali was involved in all the battles against infidels. But three caliphs were among the Qa'edin. Therefore this verse aims to prefer Imam Ali over others" (Mojahed (Rasht), 9 Shawwal 1325: 1).

Ejtemaioun considered themselves as "real defenders" and "Mojahedin" of Islam (Pavlovic, 1357: 38) and believed that their plans are in full accordance with the Islamic Sharia. Mojahed newspaper, in one of its issues insists on the necessity for developing science and establishment of new schools to promote it in Iran and refers to the efforts of the Prophet "in training people" more than anyone and at any time and stipulations of holy Qur'an verses on this issue. It believes that acquiring knowledge and education to develop the country is in a sense the same as "protecting the rights of the country". It tells its readers that all the laws of "Russia and Britain and other European nations" which have considered this issue, all of them have been written according to holy Qur'an and this is while we as Muslims disregard Hadiths and traditions of "Prophet and Imams" in this context (Mojahed (Rasht), 4 Dhu al-Hijjah 1325: 2 and 1).

Ejtemaioun even tried to prove that socialistic principles are in agreement with Islam. In this context, they introduced the land ownership reformation plan by referring to Quran verses and Hadiths. Souresrafil says: "The holy religion is more than any other religion in accordance with socialistic principles" (Souresrafil, 12 Rabi Thani 1326: 2).

Since formation of Ejtemaioun Ammioun party coincided with the activities related to constitutional revolution, so this party set its programs by considering this movement and its transformations and it began to fight, along with other constitutionalists. Not only programs of Ejtemaioun Ammioun stipulated on maintaining the Constitutionalism and they considered themselves as a part of it, but different branches and the Caucasus center expressed their support for the constitutional movement, by issuing statements. The first statement was issued on 24 Jumada Al-Awwal 1324/24 Mordad 1285, by which the Ejtemaioun Ammioun announced their presence in Iran's political scene. They congratulated Iranians for the issuance of Constitution by Mozaffar Din Shah and establishment of the National Assembly (Shakeri, 1384: 215). They also insisted on the need for preserving and supporting the constitutionalism in other statements (Tamaddon, 24 Dhu al-Hijjah 1325, 2). They also supported those religious scholars -who were among the members of constitutionalism movement- by issuing declarations and statements (Nazem Al IslamKermani, 1363: 519).

\section{Conclusion}

It should be noted that we cannot consider Ejtemaioun Ammioun as a perfect social-democratic party, like Russian Social Democratic Labour Party or European parties. Despite the fact that many Social Democratic principles were considered in compilation of this party's plans and organizational objectives, but this party was composed of different trends and social compositions. Many of those who joined the party, even at the leadership level hadn't an exact knowledge and understanding about this ideology and even if they knew it, certainly they did not have an academic and scientific knowledge. These people believed that this idea is a progressive idea, 
perhaps because it paid special attention to realize the rights of poor people in the society. Also, at the lower levels this tendency toward Ejtemaioun Ammioun was more than anything due to the need for establishment of regular organizations to implement the Constitutional Revolution. These were those pragmatic people who did not pay much attention to theoretical principles. Declining their activities after the conquest of Tehran and subsiding the revolutionary spirit and atmosphere was the result of such a reality.

Anyway, socialistic ideology -although not very extensive- was for the first time raised in Iran by Ejtemaioun Ammioun and therefore it found its way to the programs of parties such as the Democratic Party of Iran and other social democratic parties. This was the beginning of a broader discussion of this dialogue in Iran's political and sectarian sphere. The special feature of Ejtemaioun Ammioun in this regard was that they integrated and mixed this ideology with religion and proved that it is in full compliance with the principles of religion and this feature was unprecedented among social democratic parties. Perhaps this issue urged those Iranians who believed in Marxist ideology to combine religion with socialist principles in some cases and in some parties. Formation of the Ejtemaioun Ammioun not only was the beginning of partisanship in Iran, but it was the birth of a movement in the contemporary history of Iran, as well; a movement which was formed as a result of exposing Iranians to socialist ideas, within the political atmosphere of Caucasus.

\section{References}

A letter of Sattar Qazvin to Sattar Rasht Committee: Afshar, Iraj (to work), (1359), new bonds Finder constitutionalism and the role of Taghizadeh, first edition, Tehran: Javidan publication.

A sheet of constitutional history of Iran, Haydar Khan Amoghli: yadegar, (January 1325), Volume 3, Issue 5.

Adamiyat, F. (1388). Social democracy thought in Iranian constitution (1st ed.). Tehran: Publication of the range.

Afanasyan, S. (1370). Armenia, Azerbaijan and Georgia, translation by Houshang Mahdavi. Tehran: Mihan publication.

Afary, J. (1379). the Constitutional Revolution of Iran, translation by Reza Rezaei. Tehran: Bisoton publication.

Aliyef et al. (1360). History of Azerbaijan, translation by N. Eshaghi (1st ed.). Tabriz: Arch.

Altstadt, A. L. (1992). The Azerbaijani Turks, Power and Identity under Russian Rule. Stanford, Hoover Institution Press.

Antbah a Amyvn the Social denomination: New Iran (20 Muharram 1328), First Year, Issue 122, February 1, 1910.

Antbah a Amyvn the Social Party and the Fedayeen written Caucasus: Nazem al-Kermani, (1363), Iranian history, Volume III, Tehran, Amir Kabir Publications.

Arutunyan, P. S. (1385). the Iranian Revolution and the Bolsheviks of Transcaucasia, translated by Mohammad Nayeb-Pour (1st ed.). Tehran: Institute for Humanities Research and Development.

Azeri, A. (1352). Colonel Mohammad Taqi Khan Pesyani uprising in Khorasan. Tehran Research Institute Safi Ali Shah.

Biography of the martyrs of Tabriz, attach a September 29, 1912 Taghizadeh to Brown: Brown, Edward, (1351), letters of Tabriz, translated by Hassan Javadi, Third Edition, Tehran, Kharazmi.

Browne, E. G. (1914). The Press and Poetry of Modern Persia. Cambridge.

By a MEK: Shakir (to work), (1358), historical documents of the labor movement, social democracy and communism Iran, Volume VI, Tehran: the science.

Declaration of the Ejtemaioun Ammioun Tabriz: Habl Almatin, (2 Rajab 1325), Vol. 15, Number 4, August 12, 1907.

Ebrahimof, D. A. (1360). the emergence of the Communist Party of Iran, translation by Radnia (1st ed.). Tehran: Goyesh publication.

Ejtemaioun Ammioun Statement: Pavlovich. (1357). three articles of the Constitutional Revolution of Iran, the translation. Sober, Tehran corporation pocket books.

Fakhraee, E. (1352). Gilan Constitutional Movement (1st ed.). Tehran: Pocket Books corporation.

False famous historical, natural killer Mirza Ali Asghar Atabak: wooden, (December 1325), Volume 3, Issue 4.

Fathi, N. A. (1352). Khan's comrade visiting. Tehran: Gutenberg.

Formulary (rules) of the SPD (the Ejtemaioun Ammioun): Shakir, K., (without date), the historical record of the 
labor movement, social democracy and communism Iran, Volume I, Second Edition, Tehran: Science

Gordon, E. (1896). Persia revisited. Londo .

Hakimian, H. (1374). wages and Immigration: Iranian workers in southern Russia, translation by Monfard, A, Iran's contemporary history, Book VII. Tehran: Institute for Research and Cultural Studies.

Issawi, C. P. (1971). The economic history of Iran. Chicago.

Javid, S. (1358). missed sacrifice's of freedom. Tehran, Bita.

Kasrawī, A. (1359). History of the Iranian Constitutional Revolution (Vol. II, 15th ed.). Tehran: Amir Kabir.

Malek Zadeh, M. (1363). the Iranian Constitutional Revolution (Vol. V, 2nd ed.). Tehran: Academic Press.

Manifesto population of Ejtemaioun Ammioun Union, M., (1361), the development of constitutional political parties (Volume I and II of the National Assembly), first edition, Tehran: Gostare.

Maraghaee, Z. (1364). exploring Ibrahim Beyg itinerary, edited by A. S. Sepanlou. Tehran: Asfar.

Mujahid (Rasht): (9 Shawwal 1325), the first year, (1) and (4 Dhu al-Hijjah 1325), First Year, Issue 4.

Mujahid (Tabriz): (9 Sha'ban 1325), First Year, Issue 1 (22 Sha'ban 1325), First Year, Issue 3 (15 Ramadan 1325), the first year, No. 9; (7 Dhu Al Qaeda in 1325), Vol. first, (21) and (9 Dhu Al Qaeda in 1325), the first year (22).

Nasim Shomal: (7 Muharram 1326), No. 12 (26 Safar 1326), No. 15 (23 Rabi al-Awwal 1326), No. 17 (27 Rabi Thani 1326), (19) and (24 Muharram 1327), No. 23.

Pishevari, J. (1359). History of the Justice Party. Tehran: the science.

Planning and organization of Muslim Social Democrats, by: Ravasani, Shapur, (1363), the movement Kuchik Khan and the first Soviet Republic in Iran, printing, Tehran: publication.

Rafiei, M. (1362). Forum (organ of the State Council of Azerbaijan). Tehran, Tarighe Iran publication.

Rasul-Zadeh, M. A. (1387). reported that the Iranian Constitutional Revolution, translation Rahim, head of the NIA (1st ed.). Tehran: College students and headband.

Report Spring Rice Advardgry British consul in the Iranian Foreign Minister, score 26 Bashir, H., (1363), Blue Book, confidential British Foreign Office reports about the Iranian Constitutional Revolution, Volume I, Second Edition, Tehran: New publication.

Reza Zadeh M, Rahim. (n.d.). Haydar Khan Amvagheli (Abstract revolution) (1st ed.). Bija: Roozbeh Publication.

Roshan, M. (1352). Gilan Constitutional, notes of Rabino. Rasht: Taati bookstores.

Sardari Nia, S. (1363). the role of occult center in the Constitutional Revolution of Iran. Tabriz, Talash.

Shakeri, K. (1384). socio-economic backgrounds democratic movement and the development of social democracy (1st ed.). Tehran: Akhtaran Publication.

Sour Israfil: (21 Shawwal 1325), No. 18 (28 Shawwal 1325), No. 19 (11 Dhu al-Hijjah 1325), No. 20 (18 Dhu al-Hijjah 1325), No. 21 (Salkh Dhu al-Hijjah 1325), No. 22 (24 Muharram 1326), No. 24 (9 Safar 1326), No. 25 (21 Rabi al-Awwal 1326), No. 26 (27 Rabi al-Awwal 1326), No. 27 (12 Rabi Thani 1326), (29) and ( 24 Rabi Thani 1326), No. 30.

Soytokhoski, T. (1381). Azerbaijan, Russia (formation of national identity in a Muslim society), translation by K. Firouzmand (1st ed.). Tehran: Shadegan publication.

Statement by the Ejtemaioun Ammioun: civilization, (24 Dhu al-Hijjah 1325), the first year (50). The statement also equality in newspapers, First Year, Issue 11, 28 concerned Aljhh 1325 and of the Holy Spirit, First Year, Issue 16, 25 Dhu al-Hijjah 1325 has been published.

Taherzadeh, B. K. (1363). the rise of Azerbaijan in the Iranian Constitutional Revolution (2nd ed.). Tehran: Iqbal.

Telegraph Iranian Consulate General in the Ministry of Foreign Affairs Tbilisi, (24 Rabi Thani 1318), archival documents Ministry of Foreign Affairs, score 104, carton 25.

Telegraph official Baku to the Foreign Ministry, (17 Shawwal 1318), archival documents Ministry of Foreign Affairs, score 4825, Carton 6. 
Termynasyan, A. (1371). 1905 in the Caucasus, the Caucasus in recent history, translation by Kaveh Bayat. Tehran: Parvin.

The history of the Justice Party (why they left their homeland): Siren, (2 August 1322), the first year (44).

the letter of M. Sadikhov to the Social cult center of Baku to Tehran, Iran: Raeini, Ismail, (1358), documents and memories Haydar Khan Amoghli, Bija: Raeini varase.

Trotsky, L. (1971). 1905, New York, Random House.

Unknown document from the Social Amyvn (program Baku): Dastmalchi and shaker (to work), (without date), the historical record of the labor movement, social democracy and communism Iran, Volume XIX, unwarranted: Padzahr.

Urban written: New Iran (13 Shawwal 1327), First Year, Issue 52, October 28, 1909.

Wallerstein, I. (1974). The Rise and Future Demise of the World Capitalist System, Concepts for Comparative Analysis, Comparative Studies in Society and History, pp 387-415. http://dx.doi.org/10.1017/S0010417500007520

Yaqiykyan, G. (1386). the Soviet Union and the forest (notes an eyewitness), edited by Borzouyeh Dahgan (1st ed.). Tehran: Akhtaran.

Yazdani, S. (1391). Ejtemaioun Ammioun (1st ed.). Tehran: Ney Publication.

\section{Copyrights}

Copyright for this article is retained by the author(s), with first publication rights granted to the journal.

This is an open-access article distributed under the terms and conditions of the Creative Commons Attribution license (http://creativecommons.org/licenses/by/3.0/). 